\section{Identifying the Liquidity Effect at the Daily Frequency}

\author{
Daniel L. Thornton
}

L $t$ is widely believed that the Fed controls the overnight federal funds rate, and thereby other short-term interest rates, through open market operations. ${ }^{1}$ The Fed sells government securities, reducing the supply of reserves relative to demand, when it wants to raise the funds rate. Similarly, it purchases securities when it wants the funds rate to fall. The change in the short-term interest rates brought about by the exogenous policy actions of the monetary authority is referred to as the liquidity effect. By many accounts-public and professional-the Fed's use of this procedure is responsible for most, if not all, lower frequency variation in the federal funds rate and, thereby, other short-term interest rates at least since the late 1980s.

Despite the widespread belief in the Fed's ability to control short-term interest rates through open market operations, attempts to estimate the liquidity effect-using a variety of approaches - generally have been unsuccessful. ${ }^{2}$ Many analysts attribute this lack of success to the inability of economists to isolate the exogenous policy actions of the Fed. Hamilton (1997) notes that, most often, the Fed adjusts its policy instrument in response to new information about current or future values of output, inflation, the exchange rate, or other variables. Because of this, Hamilton argues that "the correlation between such 'policy innovations' and the future level of output of necessity mixes together the effect of policy on output with the effect of output on policy" (p. 80). This problem tends to be more severe when the monetary aggregates used to estimate the liquidity effect are only loosely associated with the policy actions of the Fed or when the data are averaged over a period of a month or more.

Hamilton suggests that "a more convincing measure of the liquidity effect" can be obtained by estimating the "instantaneous consequences of an

Daniel L. Thornton is a vice president and economist at the Federal Reserve Bank of St. Louis. The author thanks John Partlan and Robert Rasche for helpful comments. Jonathan Ahlbrecht and Stephen Majesky provided valuable research assistance. open market purchase. For daily data, Federal Reserve accounting and Trading Desk procedures suggest some quite plausible identifying assumptions that can be used to measure the instantaneous liquidity effect" (pp. 80-81). Specifically, Hamilton estimates the response of the funds rate to reserve supply shocks that are analogous to those that the Fed could create through open market operations. Hamilton finds that the funds rate responds significantly to reserve supply shocks, but only on the last two days of the maintenance period, and that the response is economically significant only on settlement Wednesdays.

I model the reserve market based on the Fed's operating procedure and show why the liquidity effect cannot be identified using Hamilton's methodology. Consistent with this analysis, I show that Hamilton's settlement-day result is fragile and due to a few settlement Wednesdays when there were unusually large changes in the funds rate. In addition, I show that there is no liquidity effect using his methodology for sample periods before and after his.

I then suggest an alternative approach to estimating the liquidity effect at the daily frequency. Specifically, I argue that the liquidity effect can be identified by estimating the change in nonborrowed reserves associated with changes in the Fed's target for the federal funds rate. If the Fed controls the federal funds rate by changing the funds rate target, reserves should change when the target is changed. Estimates of this model using data prior to 1994 suggest that, while the Fed undertakes open market operations consistent with changing the funds rate when the funds rate target is changed, the size of the actions is relatively small compared with stochastic fluctuations in reserves. One possible interpretation

1 It is arguably the case that the Federal Reserve has implemented monetary policy by targeting the short-term interest rates, particularly the federal funds rate, during much of its history (Goodfriend, 1991).

2 Some analysts like Christiano, Eichenbaum, and Evans (1997, 1996, 1994), Pagan and Robertson (1995), Bernanke and Mihov (1997a, b), and Strongin (1995) have suggested that policy actions can be identified using innovations from nonborrowed reserves in the context of a structural VAR; however, Thornton (1999b) has shown innovations to nonborrowed reserves from these models are not measures of Fed policy actions. In a similar vein, Bernanke and Blinder (1992) and Sims (1992) have suggested that policy actions of the Fed could be measured by innovations to the federal funds rate in the context of a VAR. However, the deviations from the Fed's funds rate target, which these measures capture, are better interpreted as random variation or control errors rather than policy innovations. Changes in the Fed's funds rate target occur less frequently and are more erratic than such innovations. Moreover, evidence suggests that the funds rate adapts quickly to the new target level. 
of the results is that the Fed undertakes such actions to signal target changes. Additional evidence is presented that is inconsistent with this explanation, however.

\section{THE LIQUIDITY EFFECT}

The idea that an exogenous central bankengineered increase in the nominal money stock can temporarily reduce interest rates is fundamental to most analyses of monetary policy. The liquidity effect has classical roots (e.g., Patinkin, 1965, and Humphrey, 1983b). Classical economists believed that an exogenous increase in the supply of money would increase the supply of loanable funds, causing the interest rate to fall. ${ }^{3}$ Ultimately, however, prices would rise and the interest rate would return to the previous level. ${ }^{4}$ While the real/nominal interest rate taxonomy is usually attributed to Fisher (1907), Humphrey (1983a) argues that classical economists from Thornton ([1802] 1939) on understood the distinction between real and nominal interest rates. Indeed, Thornton (p. 255) argues that the interest rate can be kept below its natural level only by continually increasing the money supply and ever rising prices.

Despite its long history in monetary economics, it appears that the phrase liquidity effect was first used publicly by Milton Friedman in a speech at the 1968 Conference on Savings and Residential Financing sponsored by the United States Savings and Loan League (Friedman, 1969). ${ }^{5}$ For Friedman, the liquidity effect was a natural extension of Keynes's theory of liquidity preference. Specifically, Friedman (1969, p. 365) notes that the "liquidity effect in simplest form is the usual textbook relationship between the quantity of money and the interest rate which says that the larger the quantity of money, the lower the interest rate will have to be to induce people to hold it."

Like his classical ancestors, Friedman saw the liquidity effect as the first of three possible effects associated with an exogenous change in the money supply. ${ }^{6}$ Friedman considered two cases. The first was a once-and-for-all central bank-engineered increase in the supply of money. An increase in the money stock causes the supply of real money balances to increase relative to demand at the current price level. Because of an implicit assumption that prices and output would be slow to adjust to the central bank's action, Friedman argued that initially interest rates would fall-there would be a liquidity effect. The increase in the real money stock coupled with the decline in interest rates would cause prices and/or output to rise until the supply and demand for real money balances were once again equal. While the path to equilibrium depended on the relative response of output and prices, Friedman assumed that money was neutral. Eventually the price level would rise to restore real money balances to their previous level.

Friedman's second experiment was dynamic. Specifically, he assumed that there was "an unanticipated jump in the rate of monetary increase" (1976, p. 367). In this case there is a third effect, which Friedman called the price anticipation effect. Faster money growth would give rise to an increase in inflation and a corresponding rise in expectations for inflation. Eventually, equilibrium would be achieved at a high nominal interest rate and an unchanged real rate. Like Thornton ([1802] 1939), Friedman (1968, p. 6) argued that the rate could be kept below its natural level only with everaccelerating money growth. ${ }^{7}$

3 Some classical economists, e.g., Ricardo, believed that the effect of money on the interest rate was inconsequential, see Humphrey (1983b) for more details.

4 In the case of Thornton ([1802] 1939) and Ricardo, this effect worked through the demand side. In the case of Wicksell, the effect was through the supply side, reducing the equilibrium stock of real money as the price level rose (see Patinkin, 1965, pp. 369-70).

5 The phrase liquidity effect appears to have first appeared in print in William Gibson's (1967) dissertation. Gibson was a student of Milton Friedman, and Bob Hetzel tells me that Friedman used the phrase in his monetary economics class in the early to mid 1960s. Hence, it seems likely that Gibson was merely using a phrase that Friedman had coined. Gibson's dissertation appeared as a Board of Governors Staff Economic Study and was subsequently published in the Journal of Political Economy (Gibson, 1970). Neither Friedman nor Gibson presented the phrase as their own and, in personal correspondence, Friedman noted that "liquidity played such an important role in Keynes's General Theory and liquidity preference became a common term after The General Theory came out [so that] if you asked me, it would have never occurred to me that I was the first person to introduce the term." Nelson (1996) also traces the use of the phrase to Friedman.

6 Friedman (1969) acknowledged the liquidity effect's classical origins by pointing out that John Stuart Mill had noted this "first-round" effect of a change in the quantity of money, indicating that Mill argued that the effect would be different if it occurred through the production of gold or through the credit market. In the former case, the initial effect would be on the wages of gold miners and the prices of commodities they consumed; in the latter case, it would be on the interest rate.

7 Despite its long tradition of being associated with the demand for money and credit, some economists (e.g., Ohanian and Stockman, 1995, and Christiano, 1991) have suggested there can be a liquidity effect in models that completely abstract from money and the financial markets. Hoover (1995, p. 30) has noted, however, that such models do not seem to "capture our intuitive understanding of the liquidity effect," suggesting that "in all of these models-including even the basic IS-LM model with a vertical LM curve - the liquidity effect seems to operate through the wrong mechanism." 


\section{A MODEL OF THE RESERVE MARKET AND THE FED'S OPERATING PROCEDURE}

The idea that the liquidity effect is inexorably linked to the interest elasticity of money demand is extended to the market for reserves. Until recently, the demand for total reserves, $T R$, was determined in large part by reserve requirements imposed on banks by the Fed. ${ }^{8}$ Specifically, banks are required to maintain reserves (vault cash and deposits at the Fed) equal to some proportion, $\tau$, $0<\tau<1$, of their reservable deposit liabilities, which make up a large portion of the supply of money. Hence, the demand for reserves is given by

$$
T R_{t}^{d}=\tau\left[f\left(i_{t}, x_{t}\right)+v_{t}\right]+E R_{t}^{d} .
$$

The demand for reservable transaction deposits is denoted by $f(i, x)$, which is a function of the public's opportunity cost of holding transaction deposits, $i_{t}$, and a vector of other variables that determine the demand for transaction deposits, $x_{t}$, and a random demand shock, $v_{t}$.

The demand for excess reserves is not well defined within the maintenance period because banks are free to alter their reserve holdings within the maintenance period so long as they hold enough reserves on a daily average basis to meet their requirement. Excess reserves become increasingly meaningful as the maintenance periods draws to a close.

Because reserves are non-interest bearing, these banks must derive an implicit benefit from holding excess reserves, $E R_{t}$, that is greater than or equal to the opportunity cost of holding them. If banks are holding excess reserves up to the point where the marginal benefit from the last dollar of excess reserves held is equal to the opportunity cost of holding it, one would expect the demand for excess reserves to be sensitive to changes in the interest rate. Indeed, some (e.g., Hamilton, 1998) model the demand for excess reserves in this manner. Nevertheless, banks' holdings of excess reserves are rather insensitive to changes in interest rates at a maintenance period frequency. One possible reason is that excess reserves are primarily held by relatively small banks that do not monitor their reserve positions closely. Hence, even if the concept of the daily demand for excess reserves were meaningful, dayto-day fluctuations in excess reserves would likely be unpredictable.
Consequently, the demand for excess reserves is assumed to have the form

$$
E R_{t}^{d}=\vartheta+\chi_{t}
$$

where $\vartheta$ is constant and $\chi_{t}$ is an i.i.d. random disturbance. One could think of $\vartheta$ as the maintenanceperiod average demand for excess reserves. While this assumption is simple, it has no important consequences for identifying the liquidity effect because, as was noted earlier, the liquidity effect depends on the demand for money and not banks' demand for excess reserves.

The quantity of total reserves that the Fed supplies is determined by the Fed's holding of government securities, $B_{t}$, borrowed reserves, $B R_{t}$, and all other factors that affect reserve supply, $F_{t}$ - primarily Treasury balances at the Fed and the float. That is,

$$
T R_{t}^{s}=B_{t}+B R_{t}+F_{t} .
$$

The quantity of reserves that the Fed supplies each day is determined by its operating procedure. According to Feinman (1993, p. 234), the Fed's current federal funds rate targeting procedure is as follows:

Each day the staff estimates the periodaverage demand for reserves by projecting required reserves against deposits and the desired excess reserves of the banking system. Subtracting the FOMC-specified level of discount window borrowing from this forecast of reserve demand yields the nonborrowed reserve path, the Desk's prime objective. Each morning the staff's forecast of nonborrowed reserves owing to market factors beyond the Fed's control (for example, Treasury balances at the Fed, float, etc.) is subtracted from the path to produce an estimate of the quantity of reserves that must be added or subtracted, on a periodaverage basis, to reach the objective.

The Fed's projected level of government securi-

8 Reserve requirements once applied to all but the currency component of M1. Over time, however, reserve requirements have encompassed a smaller proportion of M1 balances. Indeed, today a large portion of banks maintain deposits with the Fed, not to meet reserve requirements, but to process transactions on FedWire. Since the advent of "sweep" programs in 1994 (designed to reduce the effect of the reserve tax), the demand for deposits at the Fed increasingly has been determined by banks' demand for Fed services (see Anderson and Rasche, 2001). 
ties that will be needed to meet the Fed's objective, $B^{*}$, is:

$$
\begin{aligned}
B_{t}^{*} & =\tau E_{t-1}\left[f\left(i_{t}, x_{t}\right) \mid F F_{t}^{*}\right] \\
& +E_{t-1} E R_{t}^{d}-B R A S_{t}-E_{t-1} F_{t},
\end{aligned}
$$

where $E_{t-1}$ denotes the expectation operator conditional on information up to the start of the day, $F F_{t}^{*}$ denotes the Fed's target for the federal funds rate on day $t$, and $B R A S_{t}$ denotes the Federal Open Market Committee's (FOMC's) borrowed reserves assumption. ${ }^{9}$

When $B_{t}$ is larger than $B_{t}^{*}$, the operating procedure indicates a need to drain reserves. When $B_{t}$ is smaller than $B_{t}^{*}$, there is a need to add reserves. The quantity of reserves available each maintenance period is equal to the reserves supplied in accordance with the operating procedure, $B_{t}^{*}$, plus the actual level of borrowing and the level of all other factors that affect reserves, i.e.,

$$
T R_{t}^{s}=B_{t}^{*}+B R_{t}+F_{t} .
$$

Substituting for $B_{t}^{*}$ yields

$$
\begin{aligned}
T R_{t}^{s} & =\tau E_{t-1}\left[f\left(i_{t}, x_{t}\right) \mid F F_{t}^{*}\right]+E_{t-1} E R_{t}^{d} \\
& +\left(B R_{t}-B R A S_{t}\right)+\left(F_{t}-E_{t-1} F_{t}\right) .
\end{aligned}
$$

If the Desk follows this rule precisely, the amount of reserves available each day is equal to the Fed's forecast of reserve demand plus the unexpected components of the other factors that affect reserve supply $-B R_{t}$ and $F_{t}$.

To close the model and derive the reduced form, several additional assumptions are necessary. Following Hamilton (1997), I assume that the demand for reservable deposits is

$$
f\left(i_{t}, x_{t}\right)=-\lambda i_{t}+\gamma^{\prime} x_{t}
$$

and that the opportunity cost rate is the federal funds rate, i.e., $i_{t} \equiv F F_{t}{ }^{10}$ I also assume that bank borrowing is a function of the spread between the federal funds rate and the discount rate and other factors. Specifically, I assume that

$$
B R_{t}=\alpha\left(F F_{t}-D R_{t}\right)+\eta_{t},
$$

where $D R$ denotes the Federal Reserve's discount rate and $\eta$ represents all other factors that determine bank borrowing. For simplicity, I assume the process generating $F_{t}$ is mean stationary, i.e., $F_{t}=\mu+\omega_{t}$, and that the Fed makes unbiased forecasts of $F_{t}$, i.e., $E_{t-1} F_{t}=\mu$.
The official $B R A S_{t}$ changed infrequently; however, I have shown elsewhere (Thornton, 2001a) that the Desk has frequently offset changes in borrowing at the maintenance-period frequency. Given its practice of entering the market once per day in the morning, the Fed cannot offset borrowing at the daily frequency. Hence, I assume that the Desk operates to offset a proportion, $\xi, 0 \leq \xi \leq 1$, of expected borrowing, i.e.,

$$
B R A S_{t}=\xi E_{t-1}\left[B R_{t}\right] .
$$

The value of $\xi$ is a choice variable for the Desk. In the steady state the funds rate equals the funds rate target on average only if $\xi=1$. Hence, if the objective is to keep the funds rate close to the funds rate target, the Desk has an incentive to completely offset expected borrowing. ${ }^{11}$ Because the Desk has a strong incentive to offset borrowing, and there is evidence that it has done so at the maintenance period frequency, I impose the restriction $\xi=1$.

The reduced-form for the federal funds rate, total reserves, and nonborrowed reserves is

(10)

$$
\begin{aligned}
& F F_{t}=F F_{t}^{*}+\kappa\left[\tau \gamma^{\prime}\left(x_{t}-E_{t-1} x_{t}\right)-\eta_{t}-\omega_{t}+\tau v_{t}+\chi_{t}\right] \\
& T R_{t}=-\tau \lambda F F_{t}^{*}+\vartheta+\kappa\left[\tau^{2} \lambda \gamma^{\prime} E_{t-1} x_{t}+\alpha \tau \gamma^{\prime} x_{t}+\alpha \chi_{t}\right. \\
& \left.+\tau \lambda \eta_{t}+\tau \lambda \omega_{t}+\alpha \tau v_{t}\right]
\end{aligned}
$$

$N B R_{t}=-(\tau \lambda+\alpha) F F_{t}^{*}+\vartheta+\tau \gamma^{\prime} E_{t-1} x_{t}+\alpha D R_{t}+\omega_{t}$,

where $\kappa=(\tau \lambda+\alpha)^{-1}$.

Note that the equilibrium funds rate equals the Fed's funds rate target on average so long as the Desk makes unbiased forecasts of the demand for reserv-

9 Before June 1995, the borrowed reserves assumption was implicitly set by the FOMC in that it was embedded in the policy alternatives that the FOMC voted on at each meeting. The borrowed reserves assumption was changed frequently during the intermeeting period, however. Beginning with the June 30, 1995, meeting, the FOMC dropped the explicit reference to the level of seasonal plus adjustment borrowing that it believed was consistent with various policy alternatives being considered.

${ }^{10}$ Strictly speaking, this cannot be the case since individuals cannot participate in the federal funds market. In most monetary policy discussions, the opportunity cost rate is assumed to be linked to the funds rate by the expectations theory of the term structure (e.g., Goodfriend, 1991; Balduzzi, Bertola, and Foresi, 1997; and Cook and Hahn, 1989).

${ }^{11}$ See Thornton (2001a) for an analysis of why the Fed has an incentive to offset borrowing completely under other operating procedures, such as nonborrowed reserves targeting to maintain the stock of money at the target level. 
able deposits. Positive shocks to the demand for reservable deposits or excess reserves will cause the funds rate to rise relative to the target, while positive shocks to borrowing or other supply factors will cause the equilibrium funds rate to fall. The amount by which the Desk must change nonborrowed reserves to change the funds rate target by one percentage point is $-(\tau \lambda+\alpha)$, which is larger than the amount of the change in total reserves because of the restriction that the Desk completely offsets borrowing on average. If, on the other hand, $\xi$ were zero, the change in total reserves would be larger than the change in nonborrowed reserves because the change in the equilibrium funds rate would result in a change in borrowing and, hence, total reserves.

\section{THE RESERVE MARKET MODEL AND THE LIQUIDITY EFFECT}

Hamilton (1997) has suggested that the liquidity effect can be estimated at the daily frequency by estimating the response of the funds rate to a shock to the supply of reserves analogous to the shocks the Fed could create through exogenous open market operations. It is important to emphasize that, in private correspondence, Hamilton indicates that he thinks of the daily liquidity effect "as arising from (a) banks' unwillingness to borrow from the discount window unless the cost of fed funds is sufficiently high, and (b) banks' reluctance to reduce excess reserves unless the cost of fed funds is sufficiently high, not (c) the response of required reserves to interest-sensitive transactions deposits." 12 He noted that the effect could not come through (c) because the value of transaction deposits would not respond within the day to changes in the interest rate. I am sympathetic to the third point, but this is tantamount to arguing that the liquidity effect-as traditionally defined here-cannot be estimated directly using daily data.

With these caveats, I used Hamilton's model to discuss the problems with identifying the liquidity effect at the daily frequency using his approach. Specifically, Hamilton assumes that the demand for nonborrowed reserves is given by

$$
N B R_{t}^{d}=-\tilde{\lambda} F F_{t}+\tilde{\gamma}^{\prime} X_{t}+v_{t},
$$

where $X_{t}$ denotes a vector of predetermined variables. Hamilton notes that $\widetilde{\lambda}$ cannot be estimated from the conditional expectation of equation (11) because the Fed "actively chooses the supply of reserves each day in response to the value of the federal funds rate it anticipates for that day..."
(1997, p. 82). Rather than deriving a structural model of the supply of reserves based on the Fed's operating procedure, Hamilton assumes that the supply of nonborrowed reserves is given by

$$
N B R_{t}^{s}=\tilde{\delta} F F_{t}+\tilde{\psi}^{\prime} X_{t}+\tilde{\chi}_{t} .
$$

Noting that the classic solution to this problem of simultaneous equation bias is to find an instrument that is correlated with $N B R_{t}$ but not with $v_{t}$, Hamilton argues that it is not necessary to identify policy innovations, per se, as is usually done, in order to estimate the liquidity effect. Specifically, he suggests that the liquidity effect can be estimated by estimating the error the Fed makes in forecasting the Treasury balance each day. That these forecast errors are uncorrelated with shocks to money demand is evident from equation (10).

Hamilton exploits the instrumental variable approach by estimating the reduced form, derived from equations (11) and (12), i.e.,

$$
F F_{t}=\pi \varepsilon_{t}^{U}+\xi^{\prime} X_{t}+\varepsilon_{t}^{i}
$$

$$
N B R_{t}=\rho \varepsilon_{t}^{U}+\zeta^{\prime} X_{t}+\varepsilon_{t}^{R},
$$

where $\pi=-(1+\widetilde{\delta} \widetilde{\lambda})^{-1}, \rho=\widetilde{\lambda} /(1+\widetilde{\delta} \tilde{\lambda})$ and $\varepsilon_{t}^{U}$ denotes the "error that the Fed makes in forecasting the Treasury balance" (1997, p. 82). Hamilton observes estimates of $\widetilde{\lambda}$ can be inferred from estimates of $\pi$ and $\rho$, i.e., $\widetilde{\lambda}=\rho / \pi$. If $\varepsilon_{t}^{U}$ is contemporaneously uncorrelated with $\varepsilon_{t}^{i}$ and $\varepsilon_{t}^{R}$, then consistent estimates of $\pi$ and $\rho$, and, hence, $\widetilde{\lambda}$ can be obtained. ${ }^{13}$

\section{Shocks to the Treasury's Balance and the Liquidity Effect}

Note that this approach does not eliminate the identification problem, but replaces one identification problem with another. ${ }^{14}$ Specifically, this

\footnotetext{
${ }^{12}$ Hamilton (1997) is not specific about the source of the liquidity effect, stating only that it depends on the demand for reserves. Hamilton (1998) is much more specific in modeling the demand for borrowed and excess reserves.

${ }^{13}$ Note that this condition need not hold for several reasons. For exam ple, an interruption to the transportation system could cause both Treasury balances and the float to change from the Fed's expectation. See Thornton (2001b) for other reasons.

${ }^{14}$ In addition, equation (10) shows that the coefficient implied by the ratio of the estimated coefficients on $\omega_{t}$ from the reduced-form of nonborrowed reserves and the federal funds rate is $(\tau \lambda+\alpha)$ and not $\tau \lambda$. This difference should be relatively unimportant over Hamilton's sample period because borrowing was relatively small and interest insensitive, i.e., $\alpha$ is small (Thornton, 2001a).
} 
approach requires one to identify the "error that the Fed makes in forecasting the Treasury balance." Failure to correctly identify the Treasury balance component of $\omega_{t}$ will bias the estimate of the response to the funds rate. ${ }^{15}$

Evidence that Hamilton failed to correctly identify the Fed's forecast errors comes from noting in his nonborrowed reserves equation that his estimate of the coefficient on $\hat{\varepsilon}_{t}^{U},-0.42$, is considerably different from the theoretically correct value of -1 . It turns out that Hamilton's forecasts differ significantly from those used each day to implement monetary policy. Elsewhere (Thornton, 2001b), I evaluate the forecasts of the Treasury's balance made each day by the New York Fed, the Treasury, and the Board of Governors. ${ }^{16} \mathrm{~A}$ comparison of these forecasts with those from Hamilton's model shows that model-based forecast errors are significantly larger than those made by these agencies each day.

To see why this approach cannot identify the liquidity effect, note the Fed's system of reserve requirements is not strictly contemporaneous. ${ }^{17}$ Instead, banks are required to maintain reserves over a two-week period ending Wednesday based on the average deposit liabilities held over a twoweek period ending Monday, two days previous. ${ }^{18}$ Specifically, banks must satisfy the condition

$$
\begin{aligned}
& \sum_{t=1}^{14} \tau\left[f\left(i_{t-2}, x_{t-2}\right)+v_{t-2}\right] / 14+\sum_{t=1}^{14}\left[\vartheta+\chi_{t}\right] / 14= \\
& \sum_{t=1}^{14}\left[\tau E_{t-1}\left[f\left(i_{t-2}, x_{t-2}\right) \mid F F_{t}^{*}\right]+\vartheta\right. \\
& \left.+\left(B R_{t}-E_{t-1}\left[B R_{t}\right]\right)+\omega_{t}\right] / 14
\end{aligned}
$$

on the last day of the maintenance period.

Because the demand for reserves to satisfy reserve requirements is completely determined by Monday, the quantity of transaction deposits cannot respond to the federal funds rate on the last two days of the maintenance period. Since estimating the slope of this demand curve is critical to estimating the liquidity effect, it is impossible to estimate the liquidity effect on the last two days of the maintenance period.

If Hamilton's settlement-day response is not due to the liquidity effect, what accounts for it? There are a couple of possibilities. First, equation (14) shows that a reserve-supply shock that occurs on any day during the maintenance period-including settlement Wednesdays-contributes to only onefourteenth of the aggregate average imbalance at the end of the maintenance period. Consequently, it would take a $\$ 14$ billion error in forecasting the Treasury's balance to produce a $\$ 1$ billion aggregate reserve imbalance at the end of the maintenance period. Hence, it could be that there are several very large forecast errors that caused the funds rate to move significantly on a few settlement days.

Second, unusually large changes in the funds rate tend to occur more frequently on settlement Wednesdays. ${ }^{19}$ Consequently, a few unusually large settlement-Wednesday changes in the funds rate could occur on days when Hamilton estimates that there were relatively large shocks to the Treasury's balance. ${ }^{20}$ If either of these explanations is correct, Hamilton's settlement-Wednesday results should be fragile, resulting from a relatively few settlement Wednesdays when there are either very large reserve-supply shocks or relatively large changes in the funds rate.

${ }^{15}$ There are two reasons for this. First, and most important, the Desk's decisions are based on its forecast of the Treasury's balance. If estimates used are not equal to the true estimates, the forecast errors must be correlated with other factors that affect the supply of reserves. Second, there could be a scale problem. For example, assume that estimates of $\hat{\varepsilon}_{t}^{U}$ are twice as large on average as the true forecast errors made by the Desk. In this case, the estimated response would be half as large as the true response.

${ }^{16}$ That Hamilton's forecast errors do not coincide with those made by the Desk is not surprising. Each day the staffs of the Board of Governors, the New York Fed, and the Treasury all make separate estimates of Treasury balances based on knowledge of inflows and outflows from the Treasury's tax and loan accounts and knowledge of specific Treas ury financing operations being undertaken. Even with this extensive knowledge, the three estimates of Treasury balances frequently differ by large amounts. When this happens, a judgement is made in conducting that day's open market operations. It seems very unlikely that Hamilton's econometric model adequately accounts for the nuances of the actual procedure used.

${ }^{17}$ For a complete description of contemporaneous reserve accounting post-1982, see Gilbert and Trebing (1982). The lag in the structure of reserve requirements was increased in July 1998.

${ }^{18}$ The Federal Reserve reverted to a system of lagged reserve accounting in July 1998.

19 The reason is that the Fed cannot offset large unanticipated surpluses or deficits in the aggregate provision because with rare exceptions, since the early 1980s, the Desk has entered the market only once per day. In January 1997 the Desk moved up the timing of its interventions from 11:30 a.m. EST to 10:30 a.m.; in April 1999 the time was moved to $9: 30$ a.m. to allow the Desk to intervene closer to the time that the market for repurchase agreements is most liquid. It is interesting to note that Furfine (2000) finds, with the exception of settlement Wednesday, much of the intra-maintenance period variation in the funds rate is the result of predictable patterns in the level and volatility of interbank payments.

${ }^{20}$ Given the sensitivity of least squares to outliers, it is very possible that Hamilton's results are due to large funds rate changes on a few days. Hamilton reports no test of the sensitivity of his results to outliers that occur on settlement days. 


\section{Hamilton's Empirical Methodology}

To investigate the source of Hamilton's settlement-day results, I estimate his model over an extended sample period and I examine the results for his sample period in more detail. Following Hamilton, let $y_{t}$ denote the variable being studied and $x_{t}$ and $z_{t}$ denote vectors of variables that govern the mean and variance of $y_{t}$, respectively. In general,

$$
y_{t}=x_{t}^{\prime} \beta+\varepsilon_{t},
$$

where $\varepsilon_{t}=\sigma_{t} v_{t}$ and $\sigma_{t}$ is assumed to depend on current and lagged values of other variables, $Z_{t}$, and of lagged values of $v_{t}$. Hamilton chose the variables to include in $x_{t}$ based on an analysis of institutional factors and checked his specification using a variety of specification tests.

In addition, $v_{t}$ is assumed to be drawn from a mixture of normal distributions. Specifically, $v_{t} \sim N(0,1)$ with probability $p$ and $v_{t} \sim N\left(0, \tau^{2}\right)$ with probability $(1-p)$. Hamilton argues that this distribution is useful for capturing very frequent small changes and the occasional very large changes observed in the funds rate and that it produces estimates of $\beta$ that are robust to the influence of outliers. The variance of this distribution is

$$
E\left(v_{t}^{2}\right)=p+(1-p) \tau^{2} .
$$

The conditional variance of $y_{t}$ is $\sigma_{t}^{2} E\left(v_{t}^{2}\right)$. Hamilton assumes that the magnitude of $\sigma_{t}^{2}$ obeys an EGARCH model proposed by Nelson (1996). Specifically,

$$
\begin{aligned}
& \text { (17) } \ln \left(\sigma_{t}^{2}\right)-z_{t}^{\prime} \kappa= \\
& \delta\left[\ln \left(\sigma_{t-1}^{2}\right)-z_{t-1}^{\prime} \kappa\right]+\alpha\left[q\left(v_{t-1}\right)-E q\left(v_{t-1}\right)+\kappa v_{t-1}\right]
\end{aligned}
$$

After experiencing difficulty maximizing the likelihood function with $q(\cdot)=|v|$, Hamilton assumed that

$$
q\left(v_{t}\right)= \begin{cases}\left(1+v_{t}^{2}\right) / 2 & \text { for }\left|v_{t}\right|<1 \\ \left|v_{t}\right| & \text { for }\left|v_{t}\right| \geq 1\end{cases}
$$

The function given by equation (18) is smooth around zero, so that it is everywhere differentiable. The conditional log likelihood function,

$$
L=\sum_{t=1}^{T} \ln \left[f\left(y_{t} \mid I_{t}\right)\right],
$$

is maximized numerically subject to the constraint that $0 \leq p \leq 1$. The sequence $\left\{\sigma_{t}\right\}_{t=1}^{T}$ is generated recursively using equation (19), starting with $\ln \left(\sigma_{0}^{2}\right)=z_{0}^{\prime} \kappa$ and $v_{0}=0$.

\section{Results from Hamilton's Model}

Hamilton investigated the behavior of Treasury balances at the Fed, nonborrowed reserves, and the federal funds rate using daily data over the period April 6, 1989, to November 27, 1991. Hamilton's sample begins with the first Thursday in a new maintenance period and ends on a settlement Wednesday. The data used in this study also begin on the first Thursday of a new maintenance period and end on a settlement Wednesday. The sample period, January 16, 1986, to January 29, 1997, includes Hamilton's sample period.

Hamilton estimated various forms of this general model for three variables: Treasury balances at the Fed, $U_{t}$, nonborrowed reserves, $N B R_{t}$, and changes in the federal funds rate, $\Delta F F_{t}$. Hamilton's measure of nonborrowed reserves-deposit balances at the Fed less total bank borrowing from the Fed-is unconventional. The measure used here-total reserves less seasonal and adjustment borrowing - is used by the Trading Desk of the Federal Reserve Bank of New York to implement the FOMC's policy directive. The equations are estimated over three nonoverlapping periods: January 16, 1986, to April 5, 1989; April 6, 1989, to November 27, 1991; and November 29, 1991, to January 29, 1997.

Estimates of Hamilton's model for Treasury balances are presented in Table 1 for the three sample periods. In addition to lagged values of the dependent variable, $x_{t}$ includes a variety of dummy variables that capture day-of-the-week, day-of-theyear, and other special day effects (a list of these variables is provided in the Appendix).

The estimates are identical to Hamilton's for his sample period. Over other sample periods, however, the results are somewhat different. There is considerable variation for many of the parameters across samples. Nevertheless, the estimates are broadly consistent with two features of Hamilton's estimates: namely, (i) that the Treasury balances converge fairly rapidly to the control level of $\$ 5$ billion in normal circumstances and (ii) that they follow a random walk when Treasury balances exceed $\$ 8$ billion. Moreover, summary statistics for the forecast errors, reported in Table 2, suggest that overall the model performs as well, or better, over the periods before and after his. The in-sample rootmean-squared error before and after Hamilton's period is smaller than for his sample period. The same is true of the median forecast error.

The EGARCH model does not force the forecast 


\section{Figure 1}

\section{Treasury Balance Equation Residuals}

$(1 / 16 / 86-4 / 5 / 89)$

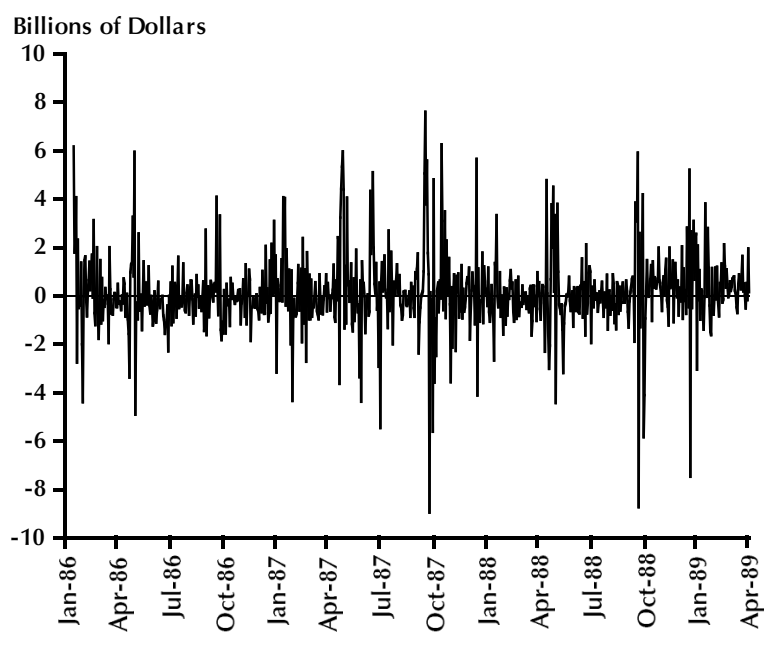

\section{Figure 2}

Treasury Balance Equation Residuals

$(4 / 6 / 89-11 / 27 / 91)$

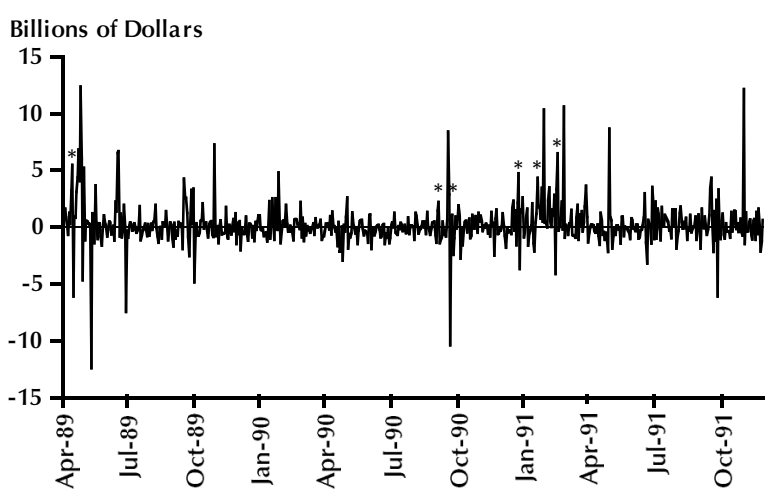

NOTE: *Indicates settlement Wednesdays when the absolute change in federal funds rate was greater than $\mathbf{0 . 8 0}$ and the absolute value of the estimated treasurey residual was greater than $\mathbf{1 . 8 5}$.

errors to be unbiased, and the average forecast error for all three periods is significantly greater than zero. The average forecast error is smaller for periods before and after Hamilton's, however. The forecast errors, plotted in Figures 1 through 3, suggest that there is no appreciable difference in the model's performance over the three periods. Furthermore, Q-statistics at various horizons show no significant

\section{Figure 3}

\section{Treasury Balance Equation Residuals}

$(11 / 29 / 91-1 / 29 / 97)$

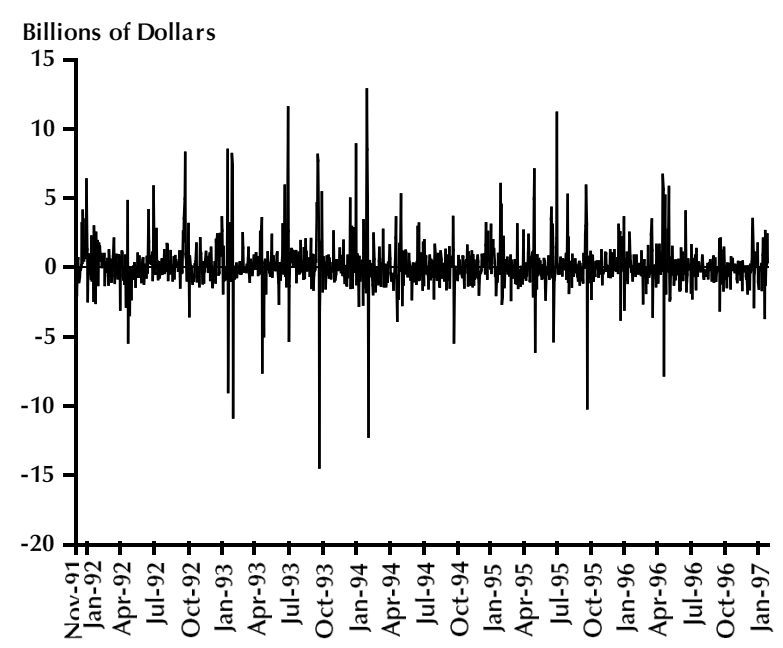

serial correlation in the series during any of the three sample periods. ${ }^{21}$

In Hamilton's model the liquidity effect is given by the estimated response of changes in the funds rate to $\hat{\varepsilon}_{t}^{U}$. Estimates of Hamilton's funds rate equation are presented in Table 3.22 My estimates of the funds rate equation for Hamilton's sample period are identical to his estimates. The liquidity effect is large and statistically significant only on settlement Wednesdays. On all other days, the response of the funds rate to $\hat{\varepsilon}_{t}^{U}$ is small and, with the exception of settlement Tuesday, not statistically significant. The estimated liquidity effect is small and not statistically significant on settlement Wednesday during the other sample periods. Indeed, the response of the funds rate to unanticipated Treasury balances on settlement Wednesday is perverse during the third sample period. Hence, there is no evidence of a liquidity effect using Hamilton's model except

${ }^{21}$ Little is gained from modeling the variance. Residuals obtained from applying OLS estimates to the mean are very similar to those presented in Figures 1 through 3. More important, none of the qualitative conclusions presented here are altered.

22 Hamilton's nonborrowed reserve equation was also estimated. (For brevity, the results are not reported here.) The results are very similar to those reported by Hamilton. Indeed, the estimate of the coefficient on $\hat{U}_{t}$ differs little from that reported by Hamilton despite the significant difference in the measures used. Moreover, the estimate of the coefficient on $\hat{U}_{t}$ was negative and statistically significant in all samples regardless of whether nonborrowed reserves or total reserves were used. This is not surprising since unanticipated increases in Treasury balances reduce both nonborrowed and total reserves. 


\section{Table 1}

Maximum Likelihood Estimates of the Model of U.S. Treasury Deposits (Dependent Variable $\left.y_{t}=U_{t}\right)$

\begin{tabular}{|c|c|c|c|c|c|c|}
\hline \multirow[b]{2}{*}{ Parameter } & \multicolumn{2}{|c|}{ 1/16/86-4/5/89 } & \multicolumn{2}{|c|}{ 4/6/89-11/27/91 } & \multicolumn{2}{|c|}{ 11/29/91-1/29/97 } \\
\hline & Estimate & SE & Estimate & SE & Estimate & SE \\
\hline Constant & 1.097 & 0.125 & 2.348 & 0.221 & 3.507 & 0.166 \\
\hline$U_{t-1}$ & 0.779 & 0.042 & 0.537 & 0.041 & 0.309 & 0.029 \\
\hline$U_{t-2}$ & -0.135 & 0.045 & -0.048 & 0.027 & 0.007 & 0.019 \\
\hline$U_{t-3}$ & 0.073 & 0.030 & 0.080 & 0.021 & 0.029 & 0.018 \\
\hline$d_{1 t}$ & -0.872 & 0.833 & -3.640 & 0.706 & -4.424 & 0.804 \\
\hline$d_{1 t} U_{t-1}$ & 0.223 & 0.064 & 0.460 & 0.068 & 0.622 & 0.080 \\
\hline$d_{1 t} \zeta_{1 t}$ & -2.947 & 2.446 & 8.919 & 1.316 & 4.646 & 1.416 \\
\hline$d_{1 t} \zeta_{1 t} U_{t-1}$ & -0.045 & 0.177 & -0.989 & 0.085 & -0.735 & 0.111 \\
\hline$d_{2 t}$ & 0.801 & 0.252 & 0.674 & 0.235 & 1.193 & 0.127 \\
\hline$d_{3 t}$ & -0.286 & 0.082 & -0.365 & 0.088 & -0.068 & 0.057 \\
\hline$\gamma_{4 t}$ & 0.043 & 0.108 & -0.458 & 0.128 & -0.227 & 0.103 \\
\hline$\zeta_{3 t}$ & -0.115 & 0.158 & -0.321 & 0.160 & 0.099 & 0.141 \\
\hline$\zeta_{4 t}$ & 0.370 & 0.150 & 0.614 & 0.174 & 0.147 & 0.121 \\
\hline$\zeta_{t}^{n}$ & 0.030 & 0.142 & 0.942 & 0.369 & 0.607 & 0.195 \\
\hline \multicolumn{7}{|c|}{ Conditional variance parameters } \\
\hline Constant & -0.372 & 0.128 & -1.135 & 0.358 & -0.937 & 0.117 \\
\hline$d_{1 t}$ & 0.629 & 0.317 & 0.894 & 0.312 & 1.253 & 0.253 \\
\hline$d_{2 t}$ & 0.972 & 0.292 & 1.327 & 0.263 & 0.552 & 0.238 \\
\hline$d_{3 t}$ & -0.030 & 0.137 & -0.748 & 0.186 & -0.298 & 0.131 \\
\hline$\zeta_{t}^{n}$ & 0.122 & 0.361 & 2.031 & 0.322 & 1.193 & 0.226 \\
\hline \multicolumn{7}{|c|}{ Other parameters } \\
\hline$\delta$ & 0.864 & 0.039 & 0.948 & 0.023 & 0.710 & 0.083 \\
\hline$\alpha$ & 0.239 & 0.058 & 0.087 & 0.036 & 0.096 & 0.049 \\
\hline$\aleph$ & 0.415 & 0.253 & 0.471 & 0.453 & 1.344 & 0.758 \\
\hline$p$ & 0.898 & 0.552 & 0.584 & 0.331 & 0.711 & 0.161 \\
\hline$\tau$ & 3.128 & 0.392 & 2.565 & 0.288 & 2.851 & 0.157 \\
\hline
\end{tabular}

NOTE: SE, standard error.

during his sample period and then only on settlement Wednesdays.

\section{Hamilton's Results Reconsidered}

The analysis presented above suggests Hamilton's results could be due to a few days when there were either unusually large forecast errors or unusually large changes in the funds rate. For the former explanation to be correct, it would take a very large forecast error. Hamilton's maximum absolute forecast error is about $\$ 12$ billion. All other things the same, shocks of this magnitude would produce about a $\$ 0.86$ billion aggregate reserve imbalance. Moreover, there were only eight shocks that were more than $\$ 8$ billion in magnitude. Given the relative small size of these shocks, it seems unlikely that Hamilton's settlement day result is due to unusually large settlement-Wednesday shocks.

To see whether Hamilton's settlementWednesday results could be due to days when there 
Table 2

\begin{tabular}{|c|c|c|c|}
\hline Statistic & $\begin{array}{c}\text { 1/16/86- } \\
4 / 5 / 89\end{array}$ & $\begin{array}{c}4 / 6 / 8- \\
11 / 27 / 91\end{array}$ & $\begin{array}{c}11 / 29 / 91- \\
1 / 29 / 97\end{array}$ \\
\hline Mean & 0.128 & 0.220 & 0.155 \\
\hline Median & 0.009 & 0.037 & 0.006 \\
\hline Minimum & -8.94 & -12.41 & -14.45 \\
\hline Maximum & 7.60 & 12.39 & 12.83 \\
\hline SD & 1.58 & 1.85 & 1.77 \\
\hline RMSE & 1.59 & 1.87 & 1.78 \\
\hline $\begin{array}{l}\text { No. of } \\
\text { observati }\end{array}$ & 809 & 666 & 1301 \\
\hline
\end{tabular}

NOTE: SD, standard deviation; RMSE, root-mean-squared error.

were unusually large changes in the federal funds rate, I identified settlement Wednesdays when the funds rate changed by more than 80 basis pointsabout two standard deviations of the daily change in the funds rate over the entire sample period. There were 10 settlement Wednesdays when the funds rate changed by more than 80 basis points. These dates are reported in Table 4, along with the associated shock to the Treasury's balance. On four of these days, the shock to the Treasury's balance was smaller than one standard deviation. There were just six settlement Wednesdays when the funds rate changed by more than 80 basis points and the shock to the Treasury's balance was relatively large (these observations are denoted with an asterisk in Figure 2).

To test the sensitivity of the results to these observations, settlement Wednesdays were partitioned into these six settlement Wednesdays and the remaining 63. Specifically, a dummy variable $l$ was created, where $l=1$ on these six days and $l=0$ elsewhere. The funds rate equation was reestimated allowing for different level and slope effects. The estimates, presented in Table 5, indicate that there is a statistically significant level effect associated with these six days. When this effect is accounted for, the response of the funds rate to the shock to Treasury balances is no different on these six days than on the remaining 63 settlement Wednesdays and is consistent with the results for the other sample periods. Moreover, in both cases the response is statistically insignificant.
Three of these days (including two of the seven largest one-day changes in the funds rate in the sample period) came in the wake of the Fed's December 26, 1990, announcement that it was reducing to zero the reserve requirement on time and savings deposits. This action took banks by surprise. As a consequence of this action, the federal funds rate became more volatile and the federal funds market did not settle down completely until late March 1991.23

These results confirm what the analysis of the reserve market suggested. The significant response to a particular reserve supply shock on the last day of the maintenance period is not due to the liquidity effect. Rather, the significant settlement-day response is due to a few settlement Wednesdays when there were unusually large and transient changes in the funds rate. ${ }^{24}$

\section{AN ALTERNATIVE METHOD OF INDENTIFYING THE LIQUIDITY EFFECT}

The analysis of the preceding section showed that it was impossible to estimate the liquidity effect directly using daily data. It is possible, however, to estimate the liquidity effect indirectly. If the Fed moves the funds rate through open market operations, as is commonly assumed, there should be a systematic relationship between changes in the Fed's funds rate target and nonborrowed reserves. Specifically, the Fed should increase the supply of reserves (relative to its expectation of demand) when it lowers the funds rate target and reduce the supply of reserves when the target is raised.

Hence, it is possible to estimate the liquidity effect by estimating the change in nonborrowed reserves associated with a change in the funds rate target. This is done by estimating the reduced form

\footnotetext{
23 The standard deviation for the daily change in the funds rate from December 26, 1990, to March 29, 1991, was 0.749 basis points, compared with 0.350 for the rest of the period from January 2, 1986, to January 31, 1997

24 John Partlan suggested another reason why Hamilton's results should be fragile: namely, that shocks to Treasury balances are small relative to other shocks. The total shock to nonborrowed reserves, $\hat{U}_{N B R}$, was obtained by subtracting from nonborrowed reserves the BOG's estimate of reserve demand and open market operations of the Desk that day. Regressing $\hat{U}_{N B R}$ on the average forecast error of the Treasury's balance, $F E_{t}^{a v g}$, over the period February 11, 1987, to December 31, 1996, yields $\hat{U}_{N B R}=-0.654(0.06)-0.994(0.07) F E_{t}^{a v g}$. The estimated coefficient on $F E_{t}^{a v g}$ is very close to and not significantly different from its theoretical value of -1 . Moreover, just as Partlan suggested, $\bar{R}^{2}=0.0776$, indicating that the error in the forecast of Treasury balances accounts for a relatively small proportion of the total shocks to nonborrowed reserves.
} 


\section{Table 3}

Maximum Likelihood Estimates of the Model of the Federal Funds Rate (Dependent Variable $\left.y_{t}=\Delta F F_{t}\right)$

\begin{tabular}{|c|c|c|c|c|c|c|}
\hline \multirow[b]{2}{*}{ Parameter } & \multicolumn{2}{|c|}{ 1/16/86-4/5/89 } & \multicolumn{2}{|c|}{ 4/6/89-11/27/91 } & \multicolumn{2}{|c|}{ 11/29/91-1/29/97 } \\
\hline & Estimate & SE & Estimate & SE & Estimate & SE \\
\hline$\phi_{1 t}$ & 0.025 & 0.012 & 0.004 & 0.008 & -0.014 & 0.010 \\
\hline$\phi_{2 t}$ & -0.029 & 0.009 & -0.042 & 0.007 & -0.081 & 0.007 \\
\hline$\phi_{3 t}$ & 0.090 & 0.009 & 0.012 & 0.006 & 0.072 & 0.007 \\
\hline$\phi_{4 t}$ & -0.061 & 0.009 & -0.022 & 0.006 & -0.067 & 0.006 \\
\hline$\phi_{5 t}$ & -0.059 & 0.009 & -0.022 & 0.006 & -0.022 & 0.006 \\
\hline$\phi_{6 t}$ & 0.007 & 0.009 & 0.011 & 0.006 & 0.026 & 0.006 \\
\hline$\phi_{7 t}$ & -0.030 & 0.009 & -0.035 & 0.006 & -0.043 & 0.006 \\
\hline$\phi_{8 t}$ & 0.098 & 0.011 & 0.030 & 0.008 & 0.115 & 0.009 \\
\hline$\phi_{9 t}$ & -0.074 & 0.012 & -0.004 & 0.008 & -0.091 & 0.012 \\
\hline$\phi_{10 t}$ & 0.097 & 0.029 & 0.125 & 0.036 & 0.172 & 0.021 \\
\hline$\phi_{1 t} \hat{\varepsilon}_{t}^{U}$ & -0.009 & 0.005 & 0.009 & 0.005 & -0.001 & 0.007 \\
\hline$\phi_{2 t} \hat{\varepsilon}_{t}^{U}$ & -0.004 & 0.006 & -0.007 & 0.006 & 0.006 & 0.006 \\
\hline$\phi_{3 t} \hat{\varepsilon}_{t}^{U}$ & 0.011 & 0.008 & 0.007 & 0.007 & 0.004 & 0.006 \\
\hline$\phi_{4 t} \hat{\varepsilon}_{t}^{U}$ & 0.013 & 0.007 & -0.003 & 0.004 & -0.001 & 0.004 \\
\hline$\phi_{5 t} \hat{\varepsilon}_{t}^{U}$ & 0.008 & 0.006 & 0.002 & 0.004 & 0.005 & 0.004 \\
\hline$\phi_{6 t} \hat{\varepsilon}_{t}^{U}$ & 0.004 & 0.005 & 0.005 & 0.003 & 0.005 & 0.002 \\
\hline$\phi_{7 t} \hat{\varepsilon}_{t}^{U}$ & -0.005 & 0.006 & -0.005 & 0.006 & 0.001 & 0.006 \\
\hline$\phi_{8 t} \hat{\varepsilon}_{t}^{U}$ & -0.002 & 0.009 & -0.004 & 0.003 & 0.013 & 0.006 \\
\hline$\phi_{9 t} \hat{\varepsilon}_{t}^{U}$ & 0.012 & 0.012 & 0.013 & 0.003 & 0.015 & 0.007 \\
\hline$\phi_{10 t} \hat{\varepsilon}_{t}^{U}$ & 0.026 & 0.027 & 0.088 & 0.037 & -0.016 & 0.013 \\
\hline$d_{11 t}$ & -0.021 & 0.035 & -0.043 & 0.024 & 0.074 & 0.073 \\
\hline$d_{12 t}$ & -0.032 & 0.018 & -0.005 & 0.015 & -0.014 & 0.013 \\
\hline$d_{13 t}$ & 0.089 & 0.036 & -0.005 & 0.023 & 0.129 & 0.036 \\
\hline$d_{14 t}$ & 0.198 & 0.021 & 0.116 & 0.028 & 0.238 & 0.019 \\
\hline$d_{15 t} s p$ & -0.770 & 0.031 & -0.831 & 0.029 & -0.648 & 0.033 \\
\hline \multicolumn{7}{|c|}{ Conditional variance parameters } \\
\hline$\phi_{1 t}$ & -4.535 & 0.203 & -5.831 & 0.245 & -4.905 & 0.173 \\
\hline$\sum_{j=2}^{7} \phi_{j t}$ & -5.204 & 0.140 & -6.211 & 0.167 & -5.601 & 0.010 \\
\hline$\phi_{8 t}$ & -4.734 & 0.207 & -5.744 & 0.250 & -4.599 & 0.169 \\
\hline$\phi_{9 t}$ & -4.428 & 0.202 & -5.644 & 0.229 & -4.326 & 0.198 \\
\hline$\phi_{10 t}$ & -2.702 & 0.204 & -2.683 & 0.271 & -3.120 & 0.166 \\
\hline$d_{7 t}+d_{9 t}$ & 1.533 & 0.635 & 0.944 & 0.469 & 1.877 & 0.436 \\
\hline$d_{8 t}+d_{10 t}$ & 1.577 & 0.320 & 2.024 & 0.414 & 2.161 & 0.315 \\
\hline$d_{9 t}$ & $0.975^{\dagger}$ & - & $0.975^{+}$ & - & $0.975^{\dagger}$ & - \\
\hline$d_{6 t}$ & NA & NA & 3.050 & 0.701 & NA & $\mathrm{NA}$ \\
\hline \multicolumn{7}{|c|}{ Other parameters } \\
\hline$\delta$ & 0.847 & 0.031 & 0.688 & 0.068 & 0.433 & 0.053 \\
\hline$\alpha$ & 0.351 & 0.049 & 0.637 & 0.071 & 0.504 & 0.047 \\
\hline$\aleph$ & 0.516 & 0.109 & -0.050 & 0.063 & 0.335 & 0.068 \\
\hline$p$ & 0.882 & 0.422 & 0.773 & 0.221 & 0.821 & 0.198 \\
\hline$\tau$ & 3.000 & 0.334 & 3.144 & 0.270 & 3.489 & 0.225 \\
\hline
\end{tabular}

NOTE: ${ }^{\dagger}$ Parameter constrained to this value; SE, standard error. 
Table 4

\section{Potential Influential Observations}

\begin{tabular}{lrr} 
Date & $\hat{\boldsymbol{\varepsilon}}_{\boldsymbol{t}}^{U}$ & $\boldsymbol{\Delta} \boldsymbol{F} \boldsymbol{F}_{\boldsymbol{t}}$ \\
\hline $4 / 19 / 89^{\dagger}$ & 5.50 & 1.00 \\
$5 / 16 / 90$ & -1.47 & -0.81 \\
$8 / 22 / 90$ & -0.26 & 0.96 \\
$9 / 5 / 90^{\dagger}$ & 2.24 & 1.14 \\
$9 / 19 / 90^{\dagger}$ & 2.89 & 1.66 \\
$10 / 31 / 90$ & 0.51 & 1.68 \\
$11 / 14 / 90$ & 0.13 & 0.92 \\
$12 / 26 / 90^{\dagger}$ & 4.77 & 2.41 \\
$1 / 23 / 91^{\dagger}$ & 4.36 & 2.83 \\
$2 / 20 / 91^{\dagger}$ & 6.53 & 0.87 \\
NOTE: $^{\dagger}$ Indicates settlement Wednesdays when $\left|\Delta F F_{t}\right|>0.80$ \\
and $\left|\hat{\varepsilon}_{t}^{U}\right|>1.85$. & \\
\hline
\end{tabular}

for nonborrowed reserves, i.e., estimating the nonborrowed reserves equation in equation (10). The variables include the estimate of reserve demand made by the staff of the Board of Governors, $R D^{e}$; the estimate of excess reserve demand made by the staff of the Board of Governors, $E R^{e}$; the average forecast error made by the staffs of the Federal Reserve Bank of New York, the Board of Governors, and the Treasury in forecasting the Treasury's balance at the Fed, $F E^{a v g}$; the discount rate, $D R$; and the federal funds rate target, $F F^{*}$.

There were two significant changes in reserve requirements during the sample period. On

December 27, 1990, the reserve requirement on non-personal time and savings deposits was reduced from 3 percent to zero in two stages. On April 2, 1992, the reserve requirement on transactions deposits was reduced from 12 percent to 10 percent. Theoretically, the coefficient on $R D^{e}$ is equal to $\tau \lambda$, so it should change with changes in the type of deposits that are reservable and with changes in reserve requirements, assuming that demand for a given type of reservable deposits is stable. Consequently, $R D^{e}$ is partitioned into the three periods of different reserve requirements using dummy variables $R R_{i}, i=1,2,3$, that equal one when the $i$ th reserve structure is in place and zero otherwise.

It is important to note that the Fed does not strictly adhere to operating procedure described by Feinman (1993). Considerable judgement is involved. Consequently, the estimated equation includes variables that do not enter the reduced form obtained from a strict interpretation of the operating procedure. One variable is the spread between the funds rate, and the funds rate target is lagged one day, $\left(F F-F F^{*}\right)_{t-1}$. There are several reasons why this variable might be important. First, if the Fed wishes to keep the funds rate close to the funds rate target, it is reasonable to assume that the Desk attempts to offset deviations of the funds rate from the target on the previous day (Taylor, 2001). An alternative explanation comes from noting that the Fed did not explicitly state the level of its funds rate target until August 1997. Consequently, the Desk could inject reserves when the funds rate is above the target and drain reserves when the funds rate is below the target to signal the level of the funds rate target to the market. Yet a third possibility comes from noting that under contemporaneous reserve accounting there is considerable uncertainty about the demand for reserves. In such instances the Desk may rely on a signal from the federal funds rate (Meulendyke, 1998, p. 180).

For any or all of these reasons, reserves could systematically increase when the funds rate is above the funds rate target the previous day and decline when the previous day's funds rate is below the target. Of course, this should not happen on days when the Fed changes the funds rate target, so this variable is included only on days when the funds rate target is not changed.

In addition, I have elsewhere shown (Thornton, 2001a) that the Desk tends to offset changes in borrowing. Hence, the spread between actual borrowing and the borrowing assumption on the previous day, $(B R-B R A S)_{t-1}$, is also included. If the Desk offsets borrowing, the coefficient on this spread should be negative and statistically significant. Finally, to estimate the extent to which the Fed systematically changes reserves when it changes the federal funds rate target, the change in the funds rate target, $\Delta F F^{*}$, is included.

The sample period is from February 11, 1987, to December 31, 1996. Beginning with its February 1994 meeting, the FOMC began announcing target changes. Prior to that, most target changes occurred during the intermeeting period. 25 Target changes have also been much less frequent since 1994 and changes have always been multiples of 25 basis

\footnotetext{
25 Of the 63 target changes made prior to February 1994, only 10 were made the day after regularly scheduled FOMC meetings. In contrast, all but two target changes after 1994 were initiated at regularly scheduled FOMC meetings. See Thornton (1996) for more details.
} 


\section{Table 5}

\section{Maximum Likelihood Estimates of the Model of the Federal Funds Rate (Dependent Variable $y_{t}=\Delta F F_{t}$ )}

\begin{tabular}{lrc} 
& \multicolumn{2}{c}{$\mathbf{4 / 6 / 8 9 - 1 1 / 2 7 / 9 1}$} \\
\cline { 2 - 3 } Variable & Estimate & SE \\
\hline$\phi_{1 t}$ & 0.007 & 0.008 \\
$\phi_{2 t}$ & -0.043 & 0.006 \\
$\phi_{3 t}$ & 0.012 & 0.006 \\
$\phi_{4 t}$ & -0.022 & 0.006 \\
$\phi_{5 t}$ & -0.022 & 0.006 \\
$\phi_{6 t}$ & 0.011 & 0.006 \\
$\phi_{7 t}$ & -0.034 & 0.006 \\
$\phi_{8 t}$ & 0.031 & 0.008 \\
$\phi_{9 t}$ & -0.004 & 0.008 \\
$(1-l) \phi_{10 t}$ & 0.123 & 0.034 \\
$l \phi_{10 t}$ & 1.251 & 0.319 \\
$\phi_{1 t} \hat{\varepsilon}_{t}^{U}$ & 0.009 & 0.005 \\
$\phi_{2 t} \hat{\varepsilon}_{t}^{U}$ & -0.001 & 0.006 \\
$\phi_{3 t} \hat{\varepsilon}_{t}^{U}$ & 0.007 & 0.006 \\
$\phi_{4 t} \hat{\varepsilon}_{t}^{U}$ & -0.003 & 0.004 \\
$\phi_{5 t} \hat{\epsilon}_{t}^{U}$ & 0.002 & 0.004 \\
$\phi_{6 t} \hat{\varepsilon}_{t}^{U}$ & 0.004 & 0.003 \\
$\phi_{7 t} \hat{\varepsilon}_{t}^{U}$ & -0.006 & 0.005 \\
$\phi_{8 t} \hat{\varepsilon}_{t}^{U}$ & -0.004 & 0.002 \\
$\phi_{9 t} \hat{\varepsilon}_{t}^{U}$ & 0.012 & 0.003 \\
$(1-l) \phi_{10 t} \hat{\varepsilon}_{t}^{U}$ & 0.044 & 0.034 \\
& & \\
\hline & &
\end{tabular}

points. It is possible that the Desk has controlled the funds rate since 1994 through what Guthrie and Wright (2000) call open mouth operations. ${ }^{26}$ Meulendyke (1998) and Hanes (1998) have also suggested this possibility. In this case, the Fed need only announce target changes and the market adjusts to the new target level. Consequently, the sample is partitioned into the periods February 11 , 1987, to January 31, 1994, and February 1, 1994 , to December 31, 1996.

\section{The Pre-1994 Results}

Estimates of the nonborrowed reserves equation for the first period are reported in the first two columns of Table 6 . Not all of the estimates conform to the structural model of the reserve market. For example, neither the coefficient on the funds rate
4/6/89-11/27/91 cont'd

\begin{tabular}{lcc}
\cline { 2 - 3 } Variable & Estimate & SE \\
\hline$\phi_{10 t} \hat{\varepsilon}_{t}^{U}$ & -0.041 & 0.113 \\
$d_{11 t}$ & -0.042 & 0.023 \\
$d_{12 t}$ & -0.001 & 0.015 \\
$d_{13 t}$ & -0.006 & 0.023 \\
$d_{14 t}$ & 0.102 & 0.026 \\
$d_{15 t} s p$ & -0.861 & 0.021
\end{tabular}

Conditional variance parameters

$\begin{array}{lll}\phi_{1 t} & -5.835 & 0.248\end{array}$

$\begin{array}{lll}\sum_{j=2}^{7} \phi_{j t} & -6.196 & 0.169\end{array}$

$\begin{array}{lll}\phi_{8 t} & -5.735 & 0.256\end{array}$

$\begin{array}{lll}\phi_{9 t} & -5.597 & 0.230\end{array}$

$\begin{array}{lll}\phi_{10 t} & -2.822 & 0.257\end{array}$

$\begin{array}{ccc}d_{7 t}+d_{9 t} & 0.813 & 0.412\end{array}$

$\begin{array}{lll}d_{8 t}+d_{10 t} & 1.975 & 0.464\end{array}$

$\begin{array}{lll}d_{9 t} & 0.975^{\dagger} & -\end{array}$

$\begin{array}{lll}d_{6 t} & 2.913 & 0.699\end{array}$

Other parameters

$\begin{array}{lll}\delta & 0.728 & 0.058\end{array}$

$\begin{array}{lll}\alpha & 0.617 & 0.077\end{array}$

$\begin{array}{lll}\alpha & -0.026 & 0.055\end{array}$

$\begin{array}{lll}p & 0.780 & 0.225\end{array}$

$\begin{array}{lll}\tau & 3.143 & 0.272\end{array}$

NOTE: ${ }^{\dagger}$ Parameter constrained to this value; $\mathrm{SE}$, standard error.

target nor the discount rate is correctly signed, and neither is statistically significant. Likewise, the coefficient on $E R^{e}$ is incorrectly signed, but is marginally significant at the 5 percent significance level.

The estimated coefficients on $R D^{e}$ over the three partitions are positive and highly significant, and these variables alone account for over 70 percent of the variation in nonborrowed reserves over the period. In contrast to what the theory would suggest, however, the estimates do not vary with changes in reserve requirements. Indeed, all three estimates are close to unity and the hypotheses that each is equal to unity, and that they are jointly

${ }^{26}$ Guthrie and Wright (2000) develop this idea in response to an observation made by McCallum (1995). 


\section{Table 6}

Estimates of Nonborrowed Reserves Equations: February 1, 1987, to January 31, 1994

\begin{tabular}{|c|c|c|c|c|}
\hline \multirow[b]{2}{*}{ Variable } & \multicolumn{2}{|c|}{$\boldsymbol{F F}^{*}$} & \multicolumn{2}{|c|}{$\boldsymbol{F F}^{* *}$} \\
\hline & Estimate & SE & Estimate & SE \\
\hline Constant & 2.144 & 1.841 & 2.352 & 1.836 \\
\hline$F F_{t}^{*}$ & 0.059 & 0.162 & 0.028 & 0.162 \\
\hline$D R_{t}$ & -0.064 & 0.241 & -0.011 & 0.241 \\
\hline$R R_{1} R D_{t}^{\mathrm{e}}$ & $0.975^{*}$ & 0.026 & $0.972^{*}$ & 0.026 \\
\hline$R R_{2} R D_{t}^{\mathrm{e}}$ & $0.991^{*}$ & 0.031 & $0.988^{*}$ & 0.031 \\
\hline$R R_{3} R D_{t}^{\mathrm{e}}$ & $0.990^{*}$ & 0.030 & $0.987^{*}$ & 0.030 \\
\hline$E R_{t}^{\mathrm{e}}$ & $-0.647^{*}$ & 0.310 & $-0.667^{*}$ & 0.310 \\
\hline$F E_{t}^{\text {avg }}$ & $-0.847^{*}$ & 0.066 & $-0.840^{*}$ & 0.067 \\
\hline$(B R-B R A S)_{t-1}$ & $-0.643^{*}$ & 0.084 & $-0.653^{*}$ & 0.084 \\
\hline$\Delta F F_{t}^{*}$ & $-3.768^{*}$ & 1.217 & $-3.262^{*}$ & 1.096 \\
\hline$\left(F F-F F^{*}\right)_{t-1}$ & $2.851^{*}$ & 0.242 & $2.743^{*}$ & 0.244 \\
\hline L10 & $1.527^{*}$ & 0.186 & $1.529^{*}$ & 0.187 \\
\hline D10 & $1.729^{*}$ & 0.464 & $1.662^{*}$ & 0.465 \\
\hline $\mathrm{AR}(1)$ & $0.177^{*}$ & 0.024 & $0.172^{*}$ & 0.024 \\
\hline $\operatorname{AR}(19)$ & $0.141^{*}$ & 0.024 & $0.141^{*}$ & 0.024 \\
\hline $\operatorname{Adj} R^{2}$ & 0.785 & & 0.782 & \\
\hline $\mathrm{SE}$ & 2.280 & & 2.289 & \\
\hline
\end{tabular}

NOTE: SE, standard error.

equal, cannot be rejected. One reason that these estimates differ from the theoretical values suggested in equation (10) is the demand for reservable deposits is not interest sensitive at the daily frequency. Hence, the Desk is not necessarily estimating the demand for reserves consistent with the funds rate target each day, but rather is trying to accommodate reserve demand. ${ }^{27}$

As theory predicts, the estimated coefficient on $F E^{a v g}$ is negative and highly significant. Nevertheless, the estimate differs significantly from its theoretical value of -1.28 One reason this coefficient differs from its theoretical value is the weight that the Desk gives to the three agency's forecast changes over time (for a discussion of this and other reasons, see Thornton, 2001b).

Also, consistent with my analysis elsewhere (Thornton, 2001a), the coefficient on $(B R-B R A S)_{t-1}$ is negative and statistically significant. The Desk appears to offset a significant proportion of deviations of the previous day's borrowing from the assumed level.
The coefficient on $\left(F F-F F^{*}\right)_{t-1}$ is positive and statistically significant. Hence, the Desk systematically adds reserves when the funds rate is above the target the previous day and drains when the previous day's funds rate is below the target. Unfortunately, it is impossible to know whether the Desk is (i) trying to keep the funds rate close to the funds rate target (e.g., Taylor, 2001), (ii) trying to signal the level of the funds rate target, or (iii) uncertain about reserve demand.

The coefficient on $\Delta F F_{t}{ }^{*}$ is negative and statistically significant, indicating that the Desk systematically drains reserves when the funds rate target is raised and adds reserves when the target is reduced. The estimates indicate that the actions that the Desk takes when the funds rate target is changed are mod-

\footnotetext{
${ }^{27}$ The forecasts are updated as information on deposits comes in during the maintenance period. For a description of the procedure see Meulendyke (1998, Chap. 6)

${ }^{28}$ If the residuals from Hamilton's model are used, the estimated coefficient is about -0.4 .
} 
est, however. For example, the estimate suggests that on average the Desk drains less than $\$ 1$ billion from reserves when the funds rate target is increased by 25 basis points. The relative magnitude of these actions can be seen from noting that the standard error for the nonborrowed reserves equation is about $\$ 2.3$ billion. Hence, random shocks to nonborrowed reserves are nearly 2.5 times larger than the estimate of the open market operation required to move the equilibrium federal funds rate 25 basis points.

Moreover, the average absolute value of the residual to the reserve equations is about $\$ 1.6$ billion - nearly twice as large as the estimate of the actions the Fed takes to change the funds rate target by 25 basis points. The average absolute deviation of the funds rate from the funds rate target during this period was about 17 basis points. Hence, shocks to reserves, which cause the funds rate to deviate from the target by an average of about 17 basis points, are nearly twice as large as the open market operations that are required to change the equilibrium funds rate by 25 basis points.

\section{Alternative Series of Funds Rate Target Change}

The estimated size of open market operations might be small because $\triangle F F^{*}$ includes target changes that were made to accommodate changes in reserve demand. Such changes would not represent exogenous changes in monetary policy. Recently, an unofficial Board staff series of target changes that reflect changes in monetary policy has been made available (Thornton and Wheelock, 2000). This federal funds rate target series, $F F^{* *}$, differs from the series used here prior to 1990 in that there are fewer target changes and, in some cases, the target changes differ in timing and/or magnitude.

In order to test whether the results are sensitive to the funds rate target series used, the nonborrowed reserve equation was reestimated using $F F^{* *}$. The results are presented in the last two columns of Table 6. The response of nonborrowed reserves to changes in the funds rate target is insensitive to the funds rate target series used. In particular, the coefficients on $\Delta F F_{t}^{* * *}$ and $\left(F F-F F^{* * *}\right)_{t-1}$ are nearly identical to those on $\Delta F F_{t}{ }^{*}$ and $\left(F F-F F^{*}\right)_{t-1}$. Hence, the relatively modest size of the estimates of Fed actions cannot be attributed to a mixing of endogenous and exogenous target changes.

\section{The Post-1994 Results}

It could be that open market operations are not undertaken to move the equilibrium federal funds rate, per se. Rather they are undertaken to signal a change in the target and to signal the target level. Meulendyke (1998, pp. 141-42) has suggested this possibility, stating:

[A]chieving the degree of reserve pressures specified in the directive has been interpreted since the late 1980 s to mean creating conditions consistent with the FOMC's desired Federal funds rate. That rate has generally been apparent to the banks; since 1994 it has been announced formally and in prior years it was clearly indicated through an open market operation. The rate has tended to move to the new, preferred level as soon as banks knew the intended rate, with little or no change in the amount of borrowing allowed for when constructing the path for nonborrowed reserves.

For example, the Fed could signal the level of the funds rate by injecting reserves when the funds rate is above the target and by draining reserves when the rate is below the target. On days when the funds rate target is changed, the Desk injects or drains a larger quantity of reserves to signal a change in the funds rate target. Whether intended or not, there is evidence that market analysts used such information to make judgements that the funds rate target had changed in the 1970s (Cook and Hahn, 1989, and Thornton, 1999).

It would be unnecessary to signal target changes after the Fed began announcing them in 1994. Hence, to investigate the signaling hypothesis, the nonborrowed reserve equation was estimated over the period February 1, 1994, to December 31, 1996. The estimates are presented in Table 7 . During this period, all but one target change occurred at regularly scheduled FOMC meetings. The target changes were announced the day the FOMC made the decision; but, because of the Desk's practice of entering the market once per day, these changes could not be implemented in terms of open market operations until the next day. Hence, changes in the target are aligned to the first day that the Desk could have implemented the FOMC's decision.

The results over this period are broadly similar to those over the previous period, even though nonborrowed reserves trended down as banks instituted sweep programs to avoid reserve requirements

\footnotetext{
${ }^{29}$ A trend was included in the equation for this period. The coefficient was negative but not statistically significant, so the results without the trend are reported here.
} 


\section{Table 7}

Estimate of the Nonborrowed Reserves Equation: February 1, 1994, to December 31, 1996

\begin{tabular}{lcc} 
Variable & Estimate & SE \\
\hline Constant & 0.059 & 3.019 \\
$F F_{t}^{*}$ & -0.916 & 0.695 \\
$D R_{t}$ & 1.087 & 0.748 \\
$R D_{t}^{\mathrm{e}}$ & $1.006^{*}$ & 0.050 \\
$(B R-B R A S)_{t-1}$ & $0.557^{*}$ & 0.266 \\
$F E_{t}^{a t g}$ & $-0.889^{*}$ & 0.083 \\
$\Delta F F_{t}^{*}$ & $-2.205^{*}$ & 1.451 \\
$\left(F F-F F^{*}\right)_{t-1}$ & $0.740^{*}$ & 0.354 \\
$\mathrm{~L} 10$ & $2.834^{*}$ & 0.246 \\
$\mathrm{D} 10$ & 0.844 & 0.616 \\
$\mathrm{AR}(1)$ & $0.165^{*}$ & 0.037 \\
$\mathrm{AR}(19)$ & $0.169^{*}$ & 0.037 \\
AdjR & 0.770 & \\
$\mathrm{SE}$ & 1.912 &
\end{tabular}

NOTE: SE, standard error.

(e.g., Anderson and Rasche, 2000). ${ }^{29}$ The coefficients on the funds rate target and the discount rate are correctly signed but not statistically significant at the 5 percent level. The coefficient on $R D^{e}$ is again very close to and not significantly different from unity, suggesting that the Fed accommodated the impact of sweep accounts on required reserves. The coefficient on $(B R-B R A S)_{t-1}$ is again positive and significant at the 5 percent level. The coefficient on $F E^{a v g}$ is negative and significant and not significantly different from its theoretically correct value of -1 .

The coefficient on $\triangle F F^{*}$ is smaller than for the previous period and is insignificant. This result is consistent with Meulendyke's (1998) argument that the Fed has controlled the funds rate though open mouth operations since 1994. Once the Fed began announcing target changes there was no reason to signal them through open market operations.

After 1994 all funds rate target changes were multiples of 25 basis points. Consequently, the market should have had less difficulty determining the level of the funds rate target. If the Fed is systematically responding to the difference between the funds
Table 8

Estimate of the Nonborrowed Reserves Equation: February 11, 1987, to January 31, 1994

\begin{tabular}{lcc} 
Variable & Estimate & SE \\
\hline Constant & 2.178 & 1.185 \\
$F F_{t}^{*}$ & 0.064 & 0.161 \\
$D R_{t}$ & -0.064 & 0.240 \\
$R R_{1} R D_{t}^{\mathrm{e}}$ & $0.975^{*}$ & 0.026 \\
$R R_{2} R D_{t}^{\mathrm{e}}$ & $0.991^{*}$ & 0.031 \\
$R R_{3} R D_{t}^{\mathrm{e}}$ & $0.989^{*}$ & 0.030 \\
$E R_{t}^{\mathrm{e}}$ & -0.619 & 0.310 \\
$F E_{t}^{a v g}$ & $-0.839^{*}$ & 0.066 \\
$(B R-B R A S)_{t-1}$ & $-0.641^{*}$ & 0.084 \\
$D_{B 90} \Delta F F_{t}^{*}$ & $-5.496^{*}$ & 1.632 \\
$D_{A 90} \Delta F F_{t}^{*}$ & -1.812 & 1.836 \\
$D_{B 90}\left(F F-F F^{*}\right)_{t-1}$ & $2.806^{*}$ & 0.363 \\
$D_{A 90}\left(F F-F F^{*}\right)_{t-1}$ & $2.890^{*}$ & 0.305 \\
\hline $\mathrm{L} 10_{\mathrm{D} 10}$ & $1.517^{*}$ & 0.186 \\
$\mathrm{AR}(1)$ & $1.695^{*}$ & 0.464 \\
$\mathrm{AR}(19)$ & $0.175^{*}$ & 0.024 \\
\hline$A d j R^{2}$ & $0.140^{*}$ & 0.024 \\
$\mathrm{SE}$ & 0.783 & \\
\hline & 2.280 & \\
\hline & &
\end{tabular}

NOTE: SE, standard error.

rate and the funds rate target on the previous day in order to signal the level of the funds rate target, one might expect the Desk to take smaller, and perhaps less frequent, actions after 1994. Consistent with that interpretation, the coefficient on $\left(F F-F F^{*}\right)_{t-1}$ is much smaller after 1994.

It is unlikely that the Fed controlled the funds rate through open mouth operations prior to 1994 and even less likely prior to 1990. In order for open mouth operations to work the market must know the level of the funds rate target. Elsewhere (Thornton, 1999) I argue that the market was unaware that the Fed was targeting the federal funds rate because the Fed told the public that it was targeting borrowed reserves. I also present statistical and documentary evidence consistent with the market being unaware that the Fed was targeting the funds rate until late 1990. If the market was 
unaware that the Fed was targeting the funds rate, the Fed could not have controlled the funds rate through open mouth operations. While the market was aware that the Fed was targeting the funds rate after 1990, changes in the target were not announced. Consequently, if the Fed was using open market operations to signal target changes, it would have no need to do so until after 1990.

To further investigate this possibility, the nonborrowed reserves equation was estimated partitioning $\triangle F F^{*}$ and $\left(F F-F F^{*}\right)_{t-1}$ into periods before and after November 30, 1990, using a dummy variable, $D_{B 90}$ (that equals one before December 1, 1990, and zero otherwise) and a dummy variable, $D_{A 90}$ (that is equal to one after November 30, 1990, and zero otherwise). These estimates are presented in Table 8.30

Estimates of the coefficients on $\triangle F F^{*}$ differ significantly over the two samples. The coefficient is statistically significant before December 1990 but not after, which is inconsistent with the signaling hypothesis. It is more consistent with the hypothesis that the Fed was trying to move the funds rate through open market operations. While the coefficient before 1990 is about 40 percent larger than that over the entire sample period, the estimate is still small relative to the standard error of nonborrowed reserves. Moreover, the relatively small and insignificant coefficient after 1990 is inconsistent with either the open market or open mouth alternatives.

In contrast to the marked difference in the estimates of the coefficients on $\triangle F F^{*}$, the coefficients on $\left(F F-F F^{*}\right)_{t-1}$ are statistically significant and nearly identical. Indeed, the null hypothesis that they are equal cannot be rejected. Reconciling these estimates is difficult. It could be that the significant coefficient on $\left(F F-F F^{*}\right)_{t-1}$ arises because of uncertainty with the Desk's estimates of reserve demand, as Meulendyke (1998) and others have suggested. If this explanation accounts for the significant relationship between nonborrowed reserves and $\left(F F-F F^{*}\right)_{t-1}$, why did the relationship weaken after 1994 ?

\section{Is There a Liquidity Effect at the Daily Frequency?}

The evidence presented here suggests that there may not be a liquidity effect at the daily frequency. While the evidence is that the Fed systematically adjusted nonborrowed reserves in a manner that is consistent with moving the equilibrium funds rate, it did so only before December 1990. After 1990 there is no statistically significant systematic relationship between changes in nonborrowed reserves and changes in the Fed's target for the federal funds rate. Moreover, and equally important, the magnitude of the Fed actions are relatively small even before 1990. It is difficult to see how such relatively small actions could account for relatively large changes in the equilibrium federal funds rate. These results are consistent with evidence (Thornton, 1999, and Poole and Rasche, 2000) that indicates no statistically significant response of the funds rate to changes in the funds rate target. It is also broadly consistent with evidence on the dynamic relationship between the federal funds rate and the 3-month T-bill rate (Sarno and Thornton, 2000).

The evidence is broadly consistent with the suggestion by some that the Fed controls the funds rate through open mouth operations. According to this view, all the Fed need do is announce or signal the target change and the market does the rest. It is easy to see how open mouth operations could account for the lack of policy actions after 1994, when the Fed began announcing target changes. It is much more difficult to see how open mouth operations could work very effectively before 1994 . While the Fed was open about the fact that it was targeting the funds rate after 1990, target changes were not announced. Consequently, the Fed would have had an incentive to signal target changes with open market operations during the 1990-94 period.

The evidence indicates that there is no significant relationship between these variables after 1990 . Hence, the lack of a statistically significant systematic relationship between nonborrowed reserves and changes in the funds rate target after 1994 cannot be taken as strong support for the open mouth hypothesis. Hence it is impossible to conclude that the Fed has controlled the funds rate through open mouth alternatives on the basis of the evidence presented here.

Nevertheless, the lack of systematic relationship between nonborrowed reserves and changes in the Fed's funds rate target after 1990 and the relatively small estimated size of the systematic response before 1990 suggest that the Fed has not implemented target changes through open market operations. Hence, the evidence presented here is inconsistent with the conventional story of how the

\footnotetext{
30 These results are also insensitive to the target series used.
} 
Fed controls the funds rate through open market operations.

Finally, there is strong evidence that the Fed responds significantly to the previous day's deviation of the funds rate from the funds rate target. What is less clear is why the Fed responds significantly. The explanation that the Fed does this to keep the funds rate close to the target level would appear to be inconsistent with the evidence that the Fed does not implement target changes through open market operations. The explanation that the Fed does this to signal the target level would appear to be at odds with the fact that before 1990 the Fed was officially implementing monetary policy with a borrowed reserves operating procedure and with evidence presented elsewhere (Thornton, 1999) that the market was unaware that the Fed was directly targeting the funds rate until after late 1990. The evidence is consistent with the Desk using information from the funds rate when it is uncertain of its estimates of reserve demand (Meulendyke, 1998). The remaining issue is why the response became smaller after 1994.

\section{CONCLUSIONS}

Following up on work by Hamilton (1997), this paper investigates whether the liquidity effect can be identified using daily data. In so doing I derive a structural model of the reserve market based on the Fed's operating procedure. An analysis of this model shows why the liquidity effect cannot be estimated using Hamilton's methodology. Consistent with this conclusion, I show that there is no evidence of a statistically significant liquidity effect using Hamilton's methodology for periods before and after his and that the liquidity effect which he finds on settlement Wednesdays is due to a few days when there were unusually large changes in the funds rate. When these days are accounted for, there is no evidence of the liquidity effect during Hamilton's sample period.

Estimates of the reduced form of the structural model of the reserve market provide little support for the conventional view that the Fed controls the funds rate using open market operations, i.e., the liquidity effect. At times the Fed has conducted open market operations in a manner consistent with its operating objective. The size of these operations appears to be so small that they cannot account for changes in the equilibrium funds rate. The relationship between Fed actions, the funds rate, and the funds rate target appears to be much more compli- cated than is usually thought and more analysis will be required to understand it.

\section{REFERENCES}

Anderson, Richard G. and Rasche, Robert H. "Retail Sweep Programs and Bank Reserves, 1994-1999.” Federal Reserve Bank of St. Louis Review, January/February 2001, 83(1), pp. 51-72.

Balduzzi, Pierluigi; Bertola, Giuseppe and Foresi, Silverio. "A Model of Target Changes and the Term Structure of Interest Rates." Journal of Monetary Economics, July 1997, 39(2), pp. 223-49.

Bernanke, Ben S. and Blinder, Alan S. "The Federal Funds Rate and the Channels of Monetary Transmission." American Economic Review, September 1992, 82(4), pp. 901-21.

and Mihov, Ilian. "Measuring Monetary Policy.” Unpublished manuscript, 1997a.

"The Liquidity Effect and Long-Run Neutrality." Unpublished manuscript, 1997b.

Christiano, Lawrence J. "Modeling the Liquidity Effect of a Money Shock." Federal Reserve Bank of Minneapolis Quarterly Review, Winter 1991, pp. 3-34.

Eichenbaum, Martin and Evans, Charles L. "Identification and the Effects of Monetary Shocks," in Mario Blejer, Zvi Eckstein, Zvi Hercowitz, and Leonardo Leiderman, eds., Financial Factors in Economic Stabilization and Growth. Cambridge: Cambridge University Press, 1996.

and "The Effects of Monetary Policy Shocks: Evidence From the Flow of Funds." Review of Economics and Statistics, February 1996, 78(1), pp. 16-34.

and Evans, Charles L. "Modeling Money." Working Paper WP-97-17, Federal Reserve Bank of Chicago, December 1997.

Cook, Timothy and Hahn, Thomas. "The Effects of Changes in the Federal Funds Rate Target on Market Interest Rates in the 70s." Journal of Monetary Economics, September 1989, 24(3), pp. 331-51.

Feinman, Joshua. "Estimating the Open Market Desk's Daily Reaction Function.” Journal of Money, Credit and Banking, May 1993, 25(2), pp. 231-47. 
Fisher, Irving. The Rate of Interest. New York: Macmillan, 1907.

Friedman, Milton. "The Role of Monetary Policy." American Economic Review, March 1968, 58(1), pp. 1-17.

"Factors Affecting the Level of Interest Rates," in Proceeding of the 1968 Conference on Saving and Residential Financing. Chicago: United States Saving and Loan League, 1969, pp. 11-27. Reprinted in Thomas M. Havrilesky and John T. Boorman, eds., Current Issues in Monetary Theory and Policy. Arlington Heights, IL: AHM Publishing Corp., 1976, pp. 362-78.

Furfine, Craig. "Interbank Payments and the Daily Federal Funds Rate.” Journal of Monetary Economics, October 2000, 46(2), pp. 535-53.

Gibson, William E. Effects of Money on Interest Rates. Ph.D. Dissertation, University of Chicago, December 1967.

"Interest Rates and Monetary Policy." Journal of Political Economy, May/June 1970, 78(3), pp. 431-55.

Gilbert, R. Alton and Trebing, Michael E. "The New System of Contemporaneous Reserve Requirements.” Federal Reserve Bank of St. Louis Review, December 1982, 64(10), pp. 3-7.

Goodfriend, Marvin. "Interest Rates and the Conduct of Monetary Policy." Carnegie-Rochester Conference Series on Public Policy, Spring 1991, (34), pp. 7-30.

Guthrie, Graeme and Wright, Julian. "Open Mouth Operations.” Journal of Monetary Economics, October 2000, 46(2), pp. 489-516.

Hamilton, James D. "Measuring the Liquidity Effect." American Economic Review, March 1997, 87(1), pp. 80-97.

The Supply and Demand for Federal Reserve Deposit." Carnegie-Rochester Conference Series on Public Policy, December 1998, 49, pp. 1-44.

Hanes, Christopher. "Reserves, Fed Funds and Repo: How the Federal Reserve Controls Interest Rates Under Federal Funds Rate Targeting." Unpublished manuscript, 1998.

Hoover, Kevin D. "Theoretical Issues of the Liquidity Effect: Commentary." Federal Reserve Bank of St. Louis Review, May/June 1995, 77(3), pp. 26-32.
Humphrey, Thomas M. "The Early History of the Real/ Nominal Interest Rate Relationship.” Federal Reserve Bank of Richmond Economic Review, May/June 1983a, pp. 2-10.

"Can the Central Bank Peg Real Interest Rates? A Survey of Classical and Neoclassical Opinion." Federal Reserve Bank of Richmond Economic Review, Septemberl October 1983b, pp. 12-21.

McCallum, Bennett T. "New Zealand's Monetary Policy Arrangements: Some Critical Issues.” Discussion Paper No. G95/4, Reserve Bank of New Zealand, 1995.

Meulendyke, Ann-Marie. U.S. Monetary Policy \& Financial Markets. New York: Federal Reserve Bank of New York, 1998.

Nelson, Edward. "Liquidity Effects and Inflation Persistence." Unpublished manuscript, 1996.

Ohanian, Lee E. and Stockman, Alan C. "Theoretical Issues of the Liquidity Effect." Federal Reserve Bank of St. Louis Review, May/June 1995, 77(3), pp. 3-25.

Pagan, Adrian R. and Robertson, John C. "Resolving the Liquidity Effect." Federal Reserve Bank of St. Louis Review, May/June 1995, 77(3), pp. 33-54.

Patinkin, Don. Money, Interest, and Prices. 2nd Ed. New York: Harper and Row, 1965.

Poole, Willam and Rasche, Robert H. "Perfecting the Market's Knowledge of Monetary Policy." Journal of Financial Services Research, December 2000, 18(2/3), pp. 225-99.

Sarno, Lucio and Thornton, Daniel L. "The Dynamic Relationship Between the Federal Funds Rate and the Treasury Bill Rate: An Empirical Investigation." Unpublished manuscript, 2000.

Sims, Christopher A. "Interpreting the Macroeconomic Time Series Facts: The Effects of Monetary Policy." European Economic Review, June 1992, 36(5), pp. 975-1000.

Strongin, Steven. "The Identification of Monetary Policy Disturbances: Explaining the Liquidity Puzzle.” Journal of Monetary Economics, August 1995, 35(5), pp. 463-97.

Taylor, John B. "Expectations, Open Market Operations, and Changes in the Federal Funds Rate." Federal Reserve 
Bank of St. Louis Review, July/August 2001, 83(4), pp. 33-48.

Thornton, Henry. An Enquiry into the Nature and Effects of the Paper Credit of Great Britain (1802) [reprint with introduction by F.A. von Hayek]. New York: Rinehart and Company, Inc., 1939.

Thornton, Daniel L. "Does the Fed's New Policy of Immediate Disclosure Affect the Market?" Federal Reserve Bank of St. Louis Review, November/December 1996, 78(6), pp. 77-88.

"The Influence on the Federal Funds Rate:

Is It Open Market or Open Mouth Operations?" Working
Paper 1999-022B, Federal Reserve Bank of St. Louis, 1999.

“The Federal Reserve's Operating Procedure, Nonborrowed Reserves, Borrowed Reserves and the Liquidity Effect." Journal of Banking and Finance, September 2001a (forthcoming).

"How Well Does the Fed Forecast the Treasury's Balance at the Fed.” Working Paper 2001 004A, Federal Reserve Bank of St. Louis, 2001b. and Wheelock, David C. "A History of the Asymmetric Policy Directive." Federal Reserve Bank of St. Louis Review, September/October 2000, 82(5), pp. 1-16.

\section{Appendix}

\section{Discrete Variables Used in Estimating Hamilton's Model}

\section{Variable}

\begin{tabular}{ll}
\hline$\gamma_{j t}$ & 1 if $t$ falls in month $j$ for $j=1,2, \ldots, 12$ and 0 otherwise \\
$\zeta_{j t}$ & 1 if $t$ falls on business day $j$ of the month for $j=1,2, \ldots, 23$ and otherwise \\
$\zeta_{t}^{n}$ & 1 if $t$ falls on the last business day of the month and 0 otherwise \\
$\phi_{j t}$ & 1 if $t$ falls on day $j$ of a reserve maintenance period for $j=1,2, \ldots, 10$ and 0 otherwise \\
$s p$ & Spread of volume weighted average of federal funds rate from $(t-1)$ to $(t-3)$ \\
$l$ & 1 if day $t$ is one of six days when $\left|\Delta F F_{t}\right|>0.80$ and $\left|\hat{\varepsilon}_{t}^{U}\right|>1.85$ and 0 otherwise \\
$\hat{\varepsilon}_{t}^{U}$ & Estimated residual from model of $U . S$. Treasury deposits \\
$d_{1 t}$ & 1 if $U_{t-1}>8$ and 0 otherwise \\
$d_{2 t}$ & 1 if $t$ falls on a major tax-collection day (month is January, April, June or September and $t$ comes \\
$d_{3 t}$ & after the first Monday following the 15 th) and 0 otherwise \\
$d_{6 t}$ & 1 if $t$ falls on a Friday and 0 otherwise \\
$d_{7 t}$ & 1 if 10 January $1991 \leq t \leq 6$ February 1991 and 0 otherwise \\
$d_{8 t}$ & 1 if $t$ is last day of quarter 1,2, or 3 and 0 otherwise \\
$d_{9 t}$ & 1 if $t$ is the day before, the day of, or the day after the last day of quarter 1,2, or 3 and 0 otherwise \\
$d_{10 t}$ & 1 if $t$ is the last day of the year and 0 otherwise \\
$d_{11 t}$ & 1 if $t$ is two days before, the day before, the day of, the day after, or two days after the last day of \\
$d_{12 t}$ & the year and 0 otherwise \\
$d_{13 t}$ & 1 if $t$ precedes a one-day holiday and 0 otherwise \\
$d_{14 t}$ & 1 if $t$ precedes a three-day holiday and 0 otherwise \\
$d_{15 t}$ & 1 if $t$ follows a one-day holiday and 0 otherwise \\
& 1 if $t$ follows a three-day holiday and 0 otherwise \\
& 1 if $t$ is the first day of a new maintenance period or the first day of a new quarter and 0 otherwise
\end{tabular}

